Tarbawy : Jurnal Pendidikan Islam

ISSN : 2407-4462 (Cetak), 2614-5812 (Elektronik)

Vol.8, No.1. 2021, Hal. 55-59

DOI: https://doi.org/10.32923/tarbawy.v8i1.1552

\title{
EfektifitasWhatsApp sebagai Media Belajar Daring
}

\author{
Ayu Ningtiyas, Siti Fakiyah, Ulan Sari \\ ${ }^{1}$ IAIN Syaikh Abdurrahman Siddik Bangka Belitung \\ ${ }^{2}$ IAIN Syaikh Abdurrahman Siddik Bangka Belitung \\ ${ }^{3}$ IAIN Syaikh Abdurrahman Siddik Bangka Belitung
}

\section{Info Artikel :}

Diterima 25 februari 2021

Direvisi 15 maret 2021

Dipublikasikan 30 april 2021

\section{Kata Kunci:}

WhatsApp,

Belajar,

Daring

\begin{abstract}
ABSTRAK
Belajar daring pada sekolah dasar banyak menggunakan media WhatsApp. Penting untuk menelisik bagaimana efektifitas belajar daring melalui WhatsApp. Peneliti melakukan penelitian lapangan dengan pendekatan kualitatif deskriptif pada berbagai sekolah dasar. Hasilnya menunjukkan bahwa pembelajaran daring melalui WhatsApp pada sekolah dasar cendrung tidak efektif. Sangat diperlukan evaluasi peran guru juga orang tua dalam hal ini kedepan.
\end{abstract}

\section{ABSTRACT}

Online learning at primary schools using WhatsApp media a lot. It is important to explore how effective online learning is through WhatsApp. Researchers conducted field research with descriptive qualitative approaches in various elementary schools. The results show that online learning through WhatsApp in elementary schools tends to be ineffective. It is very necessary to evaluate the role of the teacher as well as parents in this matter going forward.

\section{Koresponden:}

Ayu Ningtiyas, Siti Fakiyh, Ulan Sari

Email: ayuningtiyasxx@gmail.com

\section{Pendahuluan}

Pandemi Covid-19 di dunia membuat berbagai usaha dilakukan untuk memutus mata rantai penularan. Covid-19 memaksa berbagai aspek kehidupan berubah. Pemerintah memutuskan work from home. Belajar pun diharuskan daring. Hal ini dilakukan untuk mencegah penularan yang meluas akibat interaksi yang masif. Physical distancing menjadi salah satu strategi harapan untuk memutus rantai penularan penyakit ini.

Perubahan yang dipaksa oleh Covid-19 ini begitu cepat. Menyebabkan persiapan untuk menghadapi berbagai perubahan menjadi tidak maksimal. Dunia usaha misalnya banyak mengalami kemerosotan akibat „terlambat" menyesuaikan diri. „Kebangkrutan" terlihat dari terjadinya pemutusan hubungan kerja yang besar-besaran (Aldila, 2020) (Safuroh, n.d.).

Hal ini pun dirasa oleh dunia pendidikan. Kesiapan untuk belajar daring (online) yang ditetapkan oleh pemerintah nyaris tidak ada. Sekolah dalam hal ini guru dituntut berusaha mengkreasikan belajar agar tetap berjalan meski tidak di sekolah. Dikenallah belajar daring.

Ada banyak media yang digunakan untuk belajar daring. Berbagai platform sudah lama menyediakan jasa ini. Sebut saja misalnya Google Clasroom, Rumah Belajar, Edmodo, Ruang Guru, Zenius, Google meet, Sekolahmu, Kelas Pintar. Inilah yang disebut sebagai platform microbloging (Basori, 2013).

Namun perlu waktu untuk mempelajari sistem belajar melalui platform belajar daring tersebut. Jika dipahami, ada kemungkinan memberikan dampak positif pada proses pembelajaran (Wisudawati et al., 2020). Namun, guru atau dosen sekalipun belum tentu paham penggunaan media-media ini. Apalagi orang tua dengan berbagai latar belakangnya.

Disinilah problem itu, tidak ada waktu lagi untuk mempelajari semuanya bersama-sama. Covid-19 sudah tiba-tiba datang dan memaksa semuanya untuk tetap di rumah. Maka guru harus bisa menggunakan berbagai media yang familiar digunakan orang tua. Harapannya tidak mempersulit untuk 
orang tua dalam penggunaan media tersebut. Proses belajar tetap berjalan. Salah satunya media sosial WhatsApp.

Penggunaan WhatsApp Grup sebagai media belajar banyak terjadi di tingkat sekolah dasar. Tentu karena berbabagai pertimbangan. Pada level pendidikan tinggi WhatsApp hanya salah satu media. Berbeda dengan sekolah dasar, dari survei yang dilakukan peneliti $100 \%$ belajar daring hanya menggunakan media WhatsApp grup (Rosarians et al., 2020) (Harususilo, 2020).

Menarik dan penting untuk meneliti bagaimana efektifitas belajar daring melalui WhatsApp ini. Peneliti akan mengeksplore bagaimana sistem belajar melalui media WhatsApp ini, khususnya pada level sekolah dasar. Kendala-kendala apa yang dihadapi dan bagaimana jiga respon orang tua.

\section{Hasil dan Pembahasan}

Pembelajaran daring pada sekolah dasar di Indonesia sesungguhnya keterpaksaan. Pandemi Covid-19 yang menyebar begitu cepat hingga hampir ke seluruh negara di dunia memaksa Pemerintah untuk menutup sekolah segera. Mulai tanggal 16 Maret 2020 Pemerintah meminta sekolah-sekolah di tutup (CNN, 2020) (Nufus, 2020) (Purnamasari, 2020). Meskipun sesungguhnya kesiapan untuk belajar daring nyaris belum ada.

Banyak hal yang menghambat pembelajaran daring ini misalnya jaringan internet yang tidak merata, akses internet yang mahal, bahkan ada yang belum memiliki akses internet sama sekali. Wilayah perkotaan seperti wilayah Jabodetabek, Surabaya, Bandung, Medan, Palembang dan kotakota besar lainnya akses internet ini tidak mengalami masalah yang berarti. Ditambah berbagai provider penyedia jasa internet yang bersaing untuk merebut pangsa pasar terpaksa bermain harga.

Berbeda jauh dengan wilayah terpencil, perbatasan, pedesaan, pelosok negeri ini, internet termasuk hal yang tidak mudah di dapat (Laoli, 2019). Daerah Pinang Belapis, khususnya desa Ketenong, Lebong, propinsi Bengkulu misalnya, sangat sulit mendapatkan sinyal handphone apalagi mengakses internet (Arhando, 2019). Begitu juga di pulau Halmahera, Maluku Utara akses internet sangat sulit. Kalaupun sebagian mendapat sinyal jangan bermimpi itu 4G. Otomatis tidak mudah mengakses internet. Hal inilah menyebabkan internet tergolong barang mewah yang tidak semua orang dapat mengkasesnya.

Belum lagi berbicara soal kecepatan internet. Baik internet kabel maupun mobile kecepatan internet di Indonesia masih bertengger di urutan bawah. Menurut Ookla kecepatan internet kabel Indonesia 15,5 Mbps, sedangkan kecepatan internet kabel dunia rata-rata 54,3 Mbps (CNN, 2019). Sangat jauh tertinggal.

Menyadari akan hal itu membuat Menteri Pendidikan Nadiem Makarim kaget, Rumah Belajar yang dibuat oleh Kemdikbud tidak bisa digunakan ditempat tertentu. Lalu memutuskan mengadakan pembelajaran melalui TV negara yakni TVRI mulai 13 April 2020 (Dikdas, 2020). Namun TV ini pun tidak merata dapat diakses oleh masyarakat Indonesia. Masih berkutat di kota-kota besar.

Sedangkan pemerintah jelas meminta sekolah tetap mengadakan pembelajaran meskipun dari rumah masing-masing (Atsani, 2020). Sesuai Surat Edaran Menteri Pendidikan dan Kebudayaan Republik Indonesia No. 4 Tahun 2020 Tentang Pelaksanaan Kebijakan Pendidikan dalam Masa Darurat Penyebaran Coronavirus Disease (Covid19). Maka, tidak ada jalan lain, guru dituntut kreatifitas tingkat tinggi. Ada guru yang rela mengajarkan siswanya dari rumah ke rumah karena tidak bisa daring. Ada juga siswa yang diminta datang ke rumah guru dan sebagainya. Guru berusaha menyesuaikan dengan kondisi wilayah, kemampuan orang tua dan sebagainya (Herliandry et al., 2020). Sedangkan berbagai platform aplikasi belajar daring menyulitkan guru untuk menuntut orang tua memahami. Sebenarnya, ada media video call yang dapat menjadikan guru dan siswa berkomunisi tatap muka meski beda lokasi seperti Zoom Meeting, Google Duo, Skype bahkan terbaru Facebook Masenger, WhatsApp dan sejenisnya dapat digunakan.

Namun ini membutuhkan kuota internet yang cukup besar dan stabil. Artinya pada beberapa wilayah pembelajaran daring ini tidak mudah, karena tersandung kondisi jaringan internet yang lemah bahkan tidak ada (Atsani, 2020). Jika pun ada, dapat juga memberatkan bagi orang tua dan guru ditengah pandemi yang meluluh lantahkan sendi-sendi ekonomi.

Sistem video call menghabiskan kuota internet yang besar dan pasti berbiaya mahal. Selain stabilitas internet di Indonesia sangat tidak merata. Ada jalan lain, yakni WhatsApp Group. Jika hanya komunikasi texting maka ini tidak membutuhkan kuota yang besar sehingga berbiaya rendah. Selain itu melalui WhatsApp bisa dikirimkan gambar, voice note hingga vidio. WhatsApp juga aplikasi dengan jumlah pengguna yang sangat besar (Pertiwi, 2020). Di Indonesia sendiri tahun 2019 dilaporkan 143 
Juta orang menggunakan WhatsApp (Wardani, 2019). Jadilah WhatsApp sebagai aplikasi yang paling banyak digunakan terkait dengan komunikasi guru dan orang tua selama Pandemi Covid-19 ini.

Dari survei yang dilakukan peneliti orang tua dari sekolah. Dari sekolah dasar Negeri yang ada di desa, hasilnya menunjukkan semua menggunakan WhatsApp grup sebagai media komunikasi dalam belajar daring anak-anak mereka. Kesemua yang diteliti adalah orang tua siswa sekolah dasar dari kelas 1 hingga kelas 6.

Ketika peneliti menelisik efektifitas penggunaan WhatsApp sebagai media pembelajaran mayoritas orang tua menyimpulkan tidak efektif. Hal ini menjadi kritik keras bagi sekolah khususnya guru atas „ketidak percayaan“ orang tua pada media yang digunakan guru. Artinya orang tua menganggap guru kurang kreatif. Kenyataannya, memang sekolah daring ini memperlihatkan bagaimana kreatifitas guru. Ada yang hanya setiap jadwalnya memberikan tugas untuk dikerjakan pada buku halaman ini hingga halaman ini. Bahkan sebagaian guru mati kutu, tak dapat melakukan pembelajaran daring karena merekapun tak menguasai berbagai platform pembelajaran daring.

Berbeda dengan peneliti, kesimpulan penelitian Dewi menyatakan bahwa pembelajaran daring di sekolah dasar dapat terlaksana cukup baik (Dewi, 2020). Meskipun ia mensyaratkan adanya kerjasama antara guru dan orang tua. Namun ketika lingkungan termasuk media belajarnya tidak memadai maka pembelajaran akan sangat diragukan efektifitasnya. Hal ini dapat dilihat juga dengan kesimpulan penelitian Sobron dkk., bahwa pembelajaran daring dengan aplikasi Edmodo signifikan dalam meningkatkan hasil belajar (Sobron A.N et al., 2019). Pemanfaatan Rumah Belajar Kemendikbud juga dapat berdampak positif pada proses pembelajaran di masa pandemi ini (Yanti et al., 2020). Artiya aplikasi sebagai media memberikan dampak yang berbeda-beda pada proses pembelajaran. Tergantung bagaimana penggunaanya.

Sesungguhnya pembelajaran daring membutuhkan effort yang besar dari guru dan orang tua, tidak sesederhana yang banyak terjadi. Bagaimana tidak, guru dan orang tua dituntut menciptakan lingkungan belajar yang integratif dan memenuhi berbagai komponen esensial pembelajaran yakni diskursif, adaptif, interaktif dan reflektif (Oktavian \& Aldya, 2020). Tentu ini diawali dengan pelatihan untuk sama-sama memahami aplikasi yang digunakan (Ulfah \& Suryantoro, 2020). Artinya kesiapan semua pihak adalah mutlak dibutuhkan.

Bagaimana sebenarnya proses pembelajaran via WhatsApp grup ini. Kebanyakan guru memberikan tugas tertentu sesuai dengan jadwal pembelajaran biasa. Tugas ini bisa membaca buku

pelajaran yang sudah dimiliki juga mengerjakan latihan-latihan yang ada. Sayangnya, penjelasan detil dari guru melalui pesan grup apalagi video cukup jarang didapat. Padahal video penjelasan atau tutorial dapat memberikan pemahaman lebih baik dibandingkan hanya diberikan soal latihan-latihan saja (Batubara \& Batubara, 2020).

Selain itu, satu kesulitan yang wajar dialami oleh orang tua dalam proses ini adalah terkait latar belakang orang tua yang sangat variatif. Untuk orang tua yang berpendidikan tinggi membimbing anaknya belajar pada tingkat sekolah dasar tidak terlalu sulit. Itupun tidak pada semua mata pelajaran, pada mata pelajaran tertentu tetap saja orang tua tidak mudah mempelajari dan membimbing anaknya. Ini yang disebut oleh satu orang tua sebagai overburden orang tua. Wajar sebagian orang tua mengeluhkan hal ini. Mereka dilema dengan berbagai kesibukannya terpaksa juga harus meluangkan waktu lebih untuk mempelajari pelajaran anak-anaknya. Komentar-komentar ,frustasi“ orang tua akan hal ini sangat banyak tersebar diberbagai media sosial. Guru dituntut untuk memahami hal ini. Memberikan penjelasan yang sederhana atau tutorial sangat penting untuk memudahkan orang tua.

Hal lain yang menyulitkan orang tua adalah ketika keduanya tetap harus bekerja keluar rumah. Waktu yang dimiliki di rumah sangat minim yakni pagi sekali atau nanti sorenya hingga malam. Sementara tugas akan diberikan pada setiap paginya. Tugas tersebut diberikan melalui gawai orang tuanya. Anak-anak yang tinggal bersama pengasuhnya tentu tidak dapat diharapkan belajar dan mengerjakan tugas yang diberikan oleh gurunya.

Problem lainnya adalah bosennya anak belajar setiap hari tanpa teman. Belajar bersama teman sebaya tentu berbeda rasanya dengan belajar hanya ditemani ayah ibu. Kompetisi positif antar teman sebaya mendorong anak belajar lebih baik. Selain itu, teman sebaya memang memberikan pengaruh yang cukup besar dalam berbagai prilaku anak (Lestari et al., 2020). Candaan dan komunikasi dengan teman memberikan dampak menyenangkan bagi anak. Meskipun belajar di rumah tidak berlangsung lama, tugas dikerjakan dalam beberapa jam saja. Rata-rata berkisar 1-2 jam per hari. Sisanya anak-anak akan bebas bermain bersama teman-temannya. Hal ini lah yang menjadikan anak-anak tetap lebih senang belajar di rumah dibandingkan di sekolah. Free time nya lebih banyak, mereka lebih bebas berekplorasi. 
Belajar di sekolah tentu pelajaran akademisnya sesuai dengan struktur kurikulum. Di Indonesia struktur kurikulum masih sangat padat. Kurikulum 2013 implementasinya juga masih jauh dari ideal (Damanik, 2013). Berbeda dengan di rumah, guru terlihat lebih menyederhanakan pembelajaran. Makanya di rumah waktu belajar bisa lebih pendek.

Selain itu, proses internalisasi prilaku dari pembelajaran daring ini juga diragukan oleh orang tua. Pembelajaran lebih condong pada aspek kognitif. Meskipun sebagai sekolah tetap memperhatikan aspek afektif dan psikomotorik misalnya dengan menugaskan untuk mempraktikkan ibadah tertentu, membantu orang tua dan sebagainya dilaporkan secara kontinyu. Ada juga tugas untuk berolah raga. Namun ini tidak banyak, jauh lebih sedikit dari aspek kognitif. Bahkan di beberapa sekolah nyaris tidak ada tugas ini. Kalaupun ada aspek afektif dan psikomotorik efektifitasnya diragukan (Oktavian \& Aldya, 2020).

Kedepan pembelajaran online ini perlu dievaluasi secara menyeluruh. Kapasitas guru dan kemampuan orang tua mesti menjadi salah bahan pertimbangan yang penting. Perlu upaya serius dari semua pihak untuk membangun sistem pembelajaran daring yang efektif. Tidak lagi sistem pembelajaran daring rendah kualitas ditolerir dengan alasan disaat pandemi. Apalagi pandemi ini belum diketahui kapan akan bisa hilang. Kuat dugaan tidak akan terjadi dalam waktu dekat.

\section{Kesimpulan}

Penggunaan WhatsApp sebagai media pembelajaran daring kurang efektif dalam mencapai tujuan pembelajaran. Hal ini disebabkan berbagai faktor, diantaranya kurangnya penjelasan yang komprehensif dan sederhana dari guru, rendahnya aspek afektif dan psikomotorik pada pembelajaran, sinyal internet, kesibukan orang tua dan latar belakang pendidikan orang tua, dari anak yangg kalangan kurang mampu juga tidak mempunyai handphone untuk belajar menggunakan WhatsApp yangg mengakibatkan siswa yang terhambat mendapatkan tugas dari guru.

\section{Referensi}

Abdurrahman. (2019). Upaya Meningkatkan Perkembangan Nilai Agama dan Moral Melalui Metode Keteladanan pada Anak Usia Dini. Jurnal Realita, 4, 700-705.

Aldila, N. (2020, Mei). 25 Juta Orang Diperkirakan Kehilangan Pekerjaan Akibat Covid-19. https://kabar24.bisnis.com/read/20200519/15/1242794/25-juta-orang-diperkirakankehilangan-pekerjaan-akibat-covid-19

Arhando, P. (2019, September 26). Ternyata 60\% Orang Indonesia Belum Nikmati Internet. https://lifepal.co.id/media/penggunaan-internet-masih-timpang-di-indonesia-ini-faktanya/

Atsani, L. (2020). Transformasi Media Pembelajaran pada Masa Pandemi Covid-19. 1, 44-45.

Basori. (2013). Pemanfaatan Social Learning Network "Edmodo" dalam Membantu Perkuliahan Teori Bodi Otomotif di Prodi PTM JPTK FKIP UNS. JIPTEK, VI, 99-105.

Batubara, H. H., \& Batubara, D. S. (2020). PENGGUNAAN VIDEO TUTORIAL UNTUK MENDUKUNG PEMBELAJARAN DARING DI MASA

CNN, T. (2019, February 3). Kecepatan Internet Indonesia ke-2 Terbawah dari 45 Negara. https://www.cnnindonesia.com/teknologi/20190201152441-185-365734/kecepataninternet-indonesia-ke-2-terbawah-dari-45-negara

CNN, T. (2020, March 14). Anies Tutup Sekolah Dua Pekan dan Tunda Ujian Nasional di DKI. https://www.cnnindonesia.com/nasional/20200314131859-20-483393/anies-tutup-sekolahdua-pekan-dan-tunda-ujian-nasional-di-dki

Daheri, M., \& Warsah, I. (2019). Akhlak: Relasi antara Sekolah dan Keluarga. At-Turats : Jurnal Pemikiran Pendidikan Islam, 13, 3-20.

Damanik, C. (2013, Mei). Jarak Idealisme Kurikulum dan Realitas. https://edukasi.kompas.com/read/2013/05/06/11252265/jarak.idealisme.kurikulum.dan.r ealitas?page $=$ all

Dewi, W. A. F. (2020). DAMPAK COVID-19 TERHADAP IMPLEMENTASI PEMBELAJARAN DARING DI SEKOLAH DASAR. 2(1), 7.

Dikdas, D. (2020, April 10). Kemendikbud Hadirkan Program 'Belajar Dari Rumah' di TVRI. http://pgdikdas.kemdikbud.go.id/read-news/kemendikbud-hadirkan-program-belajar-darirumah-di-tvri 
Harususilo, Y. (2020, March 17). Belajar di Rumah, Cara Unik Sekolah: Kirim Tugas Lewat WA Orang Tua, Apa Lagi. https://edukasi.kompas.com/read/2020/03/17/160835971/belajar-dirumah-cara-unik-sekolah-kirim-tugas-lewat-wa-orangtua-apa-lagi?page=all

Herliandry, L. D., Suban, M. E., \& Kuswanto, H. (2020). Pembelajaran Pada Masa Pandemi Covid-19. 22(1), 6.

Kurniati, E., Nur Alfaeni, D. K., \& Andriani, F. (2020). Analisis Peran Orang Tua dalam Mendampingi Anak di Masa Pandemi Covid-19. Jurnal Obsesi : Jurnal Pendidikan Anak Usia Dini, 5(1), 241. https://doi.org/10.31004/obsesi.v5i1.541

Laoli, N. (2019, March 26). Menkominfo Akui Pembangunan Jaringan Internet di Indonesia Belum Merata. https://regional.kontan.co.id/news/menkominfo-akui-pembangunan-jaringan-internet-diindonesia-belum-merata

Lestari, S., Sarean, \& Budiman, fajar. (2020). Pengaruh Literasi Akidah Akhlak Dan Teman Sebaya Terhadap Akhlak Siswa. Jurnal Al-Karim: Jurnal Pendidikan, Psikologi Dan Studi Islam, 5, 107124.

Nufus, W. (2020, March 14). Anies: Penutupan Sekolah adalah Kewenangan Daerah, Sudah Koordinasi ke Kemendikbud. https://news.detik.com/berita/d-4938973/anies-penutupan-sekolahkewenangan-daerah-sudah-koordinasi-ke-kemendikbud

Oktavian, R., \& Aldya, R. F. (2020). Efektivitas Pembelajaran Daring Terintegrasi di Era Pendidikan 4.0. Didaktis: Jurnal Pendidikan dan Ilmu Pengetahuan, 20(2). https://doi.org/10.30651/didaktis.v20i2.4763

Pertiwi, W. (2020, February 3). WhatsApp Tembus 2 Miliar Pengguna. https://tekno.kompas.com/read/2020/02/13/18190017/whatsapp-tembus-2-miliarpengguna

Purnamasari, D. (2020, March 15). Arahan Jokowi untuk Pemda: Liburkan Sekolah hingga Tingkatkan Layanan Pasien Covid-19.

https://nasional.kompas.com/read/2020/03/15/14452291/arahan-jokowi-untuk-pemdaliburkan-sekolah-hingga-tingkatkan-layanan-pasien

PANDEMI VIRUS CORONA. Muallimuna : Jurnal Madrasah Ibtidaiyah, 5(2), 21. https://doi.org/10.31602/muallimuna.v5i2.2950

Yanti, M., Kuntarto, E., \& Kurniawan, A. (2020). Pemanfaatan Rumah Belajar Kemendikbud Sebagai MOdel Pembelajaran Daring di Sekolah Dasar. Adi Widya : Jurnal Pendidikan Dasar, $5,61-68$. 